\title{
PENGARUH AGAMA SAMAWI TERHADAP PERUBAHAN SOSIAL-BUDAYA DI ASSOLOKOBAL LEMBAH BALIM
}

\author{
Oleh: \\ Albertus Heriyanto ${ }^{1}$
}

\begin{abstract}
Before their encounter with the immigrants, the Balim religious life centered in their honai adat (traditional house). However, since the presence of divine religions, the center of their ritual and spiritual life is devolving to churches or mosques, and marginalizes the role of the honai adat. The presence of divine religions has contributed to people's way of life, especially in broadening the perspective of the Balim about human beings. The extent of human relations' perspective has played a major role in relativizing the influence of traditional values to their ways of thinking and behaving. With few exceptions, the general color manifested in the relationship between the two belief systems is the dominance of the divine religions to local one. Conversion to the divine religions and process of community building in one religion is not merely a "faith event", but also part of "the cultural process", part of a strategy to open an access to a better life in economy, socio-politics, or even in spiritual aspects. In this case, the divine religions are challenged to present their faces as the "ways of salvation" which is humane and civilized.
\end{abstract}

Abstrak: Sebelum perjumpaan mereka dengan kaum pendatang, kehidupan beragama orang Balim berpusat pada bonai adat. Namun, sejak kehadiran agama samawi pusat ritual, kiblat kehidupan spiritual itu pun beralih ke gereja atau pun masjid, dan meminggirkan peran honai adat tersebut. Kehadiran agamaagama samawi, di satu pihak memiliki andil besar terhadap terjadinya perubahan tata kehidupan masyarakat, khususnya dalam memperluas perspektif orang Balim tentang sesama manusia. Namun, luasnya perspektif relasi antar manusia itu berperan besar pula dalam merelativir kuatnya pengaruh nilai-nilai adat terhadap cara berpikir dan bertingkah laku mereka. Dengan sedikit kekecualian, warna umum yang terwujud dalam relasi antar kedua sistem kepercayaan tersebut ialah dominasi agama samawi terhadap agama setempat. Peralihan agama dan proses pembentukan komunitas dalam satu agama bukan semata-mata suatu "peristiwa iman", melainkan juga bagian dari "proses berkebudayaan", bagian dari strategi untuk membuka akses pada kehidupan yang dianggap lebih baik, entah secara ekonomi, sosial-politik, atau pun spiritual. Dalam realitas semacam

1 Dosen Tetap pada Program Studi Filsafat Agama Sekolah Tinggi Filsafat Teologi Fajar Timur, Jayapura.Email: albertus_heriyanto@yahoo.co.id 
itu agama-agama samawi kiranya ditantang untuk menghadirkan wajahnya sebagai “jalan keselamatan” yang sungguh manusiawi dan berbudaya.

Kata Kunci : Agama, Gereja, Pendeta, Tradisi, Upacara

\section{Pendahuluan}

Suatu ketika saya mengunjungi sebuah honai adat di Lembah Balim. Di dalam honai, bapak yang menemani saya sambil tersenyum berucap, "Bapa ... Kalau menurut adat, ini kami punya gereja ... Dulu, upacaraupacara adat kami buat dalam honai adat. Sekarang, agama sudah masuk, jadi kita sembayang di gereja, ... kami punya saudara yang lain di masjid."

Pada sejumlah kesempatan lain, melalui penjelasan para tetua, saya memperoleh pemahaman bahwa agama asli Balim berpusat pada sebuah benda sakral, yakni hareken ${ }^{2}$ yang tersimpan dalam honai induk. Hareken tersebut diyakini sebagai tulang-tulang Naruekul, manusia asali yang dalam mitos mereka digambarkan sebagai orang yang mengajarkan cara hidup baik kepada para leluhur orang Balim. Hareken ini tersimpan dalam sebuah honai induk, yakni honai pertama yang didirikan oleh sejumlah klen yang secara bersama membentuk satu kesatuan religius, sebelum didirikannya honai-honai adat lainnya. Dalam kehidupan sehari-hari, honai induk ini hampir terlupakan, karena hampir tidak berfungsi. Letaknya yang agak terpisah dan tersembunyi, serta gambaran akan kesakralannya yang jauh melampaui honai-honai adat yang lain dan tidak boleh dimasuki oleh sembarang orang, membuat honai tersebut jauh dari kehidupan sehari-hari orang Balim. ${ }^{3}$ Honai induk dan hareken (kaneke), yakni benda sakral yang tersimpan dalam honai inilah yang menjadi kiblat ritual mereka, yang mengikat sejumlah klen sebagai satu kesatuan religi (kanekela), yaitu kelompok yang memiliki obyek sakral bersama.

Ungkapan spontan di atas dan penjelasan para tetua tentang honai adat dan benda sakral yang kini makin memudar pengaruhnya dalam kehidupan masyarakat tersebut menyiratkan telah terjadinya perubahan besar dalam hidup beragama orang Balim. Kehadiran para pegawai pemerintah Belanda maupun Indonesia, para misionaris, guru-guru, kaum transmigran dari Jawa, pendakwah, dan para pendatang lainnya yang hingga kini terus mengalir, bukan saja mengubah wajah alam dan

2 Hareken ialah batu sakral yang menjadi simbol kehadiran para leluhur.Bentuknya pipihlonjong, berwarna hitam (biru/hijau tua kehitaman).Istilah hareken umumnya digunakan oleh kelompok klendi wilayah Lembah Balim Timur dan Selatan. Di wilayah Utara dan Barat, benda sakral yang sejenis disebut dengan nama kaneke.

3 Melengkapi kesan sakral tersebut, pada anak-anak di Assolokobal beredar mitos bahwa honai tersebut dijaga oleh seekor ular raksasa. 
kehidupan sosial di Lembah Balim, tapi juga mengubah keyakinan keagamaan orang Balim.

Pengalaman-pengalaman tersebut mengantar saya untuk berefleksi tentang bagaimana perubahan-perubahan yang terjadi dalam kehidupan orang Balim di Assolokobal akibat interaksinya dengan kaum pendatang yang membawa serta keyakinan keagamaannya, dan apa makna perubahan tersebut dalam perspektif relasi antar budaya.

\section{Persaingan yang Mengubah Kehidupan}

Terbukanya isolasi Lembah Baliem berawal pada 23 Juni1938 ketika Richard Archbold, ketua tim ekspedisi penelitian dalam bidang ilmu biologi (flora dan fauna) yang disponsori oleh American Museum of Natural History, melihat lembah hijau yang luas dari jendela pesawat. ${ }^{4}$ Tim ekspedisi yang sama di bawah pimpinan Kapten Teerink dan Letnan Van Areken mendarat di Danau Habema, di bagian Barat Lembah Balim. Dari sana mereka berjalan melalui Lembah Ibele, menyusuri Sungai Idenburg, mengeksplorasi Lembah Baliem, Puncak Wilhelmina (sekarang Gunung Trikora) dan sekitarnya (Bdk. Cookson 2000:317).

Perjumpaan orang Assolokobal -yang mendiami bagian Selatan Lembah Balim- dengan kaum pendatang diawali oleh kehadiran para misionaris CAMA (The Christian and Missionary Aliance) pada 20 April 1954. ${ }^{5}$ Dengan sebuah pesawat ampibi Pendeta Einer Mickelson dan Pendeta Lloyd van Stone mendarat di Sungai Balim, dekat Kampung Minimo. Mereka datang bersama keluarga Elisa dan Ruth Gobai, diantar oleh dua orang pilot Al Lewis dan co-pilot Edward W. Ulrich. Pada penerbangan berikutnya, datang pula Dr. Myron Bromley, Adrian Rumanderi-Rumbekwan dan Topima Gobai, serta banyak pendeta dan pembantu lainnya asal Paniai (Lieshout, 2009:28). Mereka mulanya berkemah di sisi Selatan Sungai Baliem, namun karena kebanjiran, keesokan harinya mereka menyeberangi sungai tersebut dan menuju ke Kampung Minimo. Sementara memindahkan barang, mereka bertemu dengan sejumlah orang Assolokobal. Masyarakat Minimo (Ohena) juga

\footnotetext{
4 Ini adalah perjalanan ekspedisinya yang ketiga di New Giuinea.Ekspedisi pertama (1933/1934) dan kedua (1936/1937) dilakukannya di Papua, dan ekspedisi ketiga di Netherlands New Guinea (1938/1939). Cookson mengatakan, "The 1938/39 expedition, with its reliance on Archbold's specially modified Consolidated PBY-2 flying boat, was one of the largest, most technically a technically ambitious expeditions ever attempted on the island of New Guinea."'(Cookson, 2000:313).

5 Tanggal 20 April 1954tersebut setiap tahun diperingati oleh Umat Gereja Kristen Protestan dari berbagai denominasi sebagai hari masuknya Injil ke Lembah Balim.
} 
menerima rombongan pendeta CAMA itu dengan baik, namun tempat perkemahan mereka yang baru itu adalah yukmo antara orang Assolokobal dengan orang Ohena dan Haluk-Walilo, yang pada waktu itu masih saling bermusuhan. Karena itu, pada November 1954 mereka pindah ke Selatan, di Kampung Hepuba. Setelah mendirikan pondok di Hepuba, mereka mencari lokasi untuk membuat sebuah lapangan terbang. Namun rupanya kondisi topografi di wilayah sekitar Hepuba tidak cocok, sehingga mereka melanjutkan survey lebih ke Selatan lagi, ke wilayah Hitigima. Di sana mereka menemukan dataran luas yang sesuai harapan. Mereka pun meninggalkan Hepuba, membuka lapangan terbang dan membangun tempat tinggal di Hitigima, sekitar $3 \mathrm{~km}$ dari pos mereka di Hepuba. Perpindahan ini menimbulkan kecemburuan orang Assolokobal di Hepuba pada koleganya sekonfederasi, yakni orang Assotipo di Hitigima. Orang Hepuba merasa ditinggalkan, padahal mereka telah lebih dulu menerima kehadiran para misionaris tersebut di wilayahnya. Namun, perasaan itu kemudian terobati, karena sekitar 6 tahun kemudian, pada 1960 atau 1961, datang Pastor Nico Verheyenmembuka pos pelayanan di Hepuba (Lieshout 2009:223). Kehadiran Pater Nico disambut dengan memasak daging babi dengan cara bakar batu, dan makan bersama. Dengan penerimaan seperti itu berarti mereka menerima Pater dengan tangan terbuka.

Pada waktu itu para pendeta CAMA sudah mendengar bahwa para misionaris Katolik telah menjelajah wilayah-wilayah bagian Timur dan Selatan Lembah Baliem, dan membuka pos pelayanan mereka di Wamena dan sejumlah tempat lain. Mereka khawatir para misionaris Katolik itu pun nantinya akan masuk ke Hepuba. Karena itu, para pendeta CAMA menulis sebuah peringatan di bekas pos mereka di Hepuba, bahwa tempat tersebut sudah menjadi bagian dari wilayah pelayanan CAMA.Namun, dengan kedatangan Pater Nico Verheyen, masyarakat membuang tanda larangan tersebut dan menerima Pater Nico. Hal ini sempat menimbulkan protes dari pihak CAMA, namun para tetua di Hepuba mengatakan kepada para misionaris CAMA, "Dulu kami telah menerima kalian, tapi kalian pergi meninggalkan kami dan tinggal di tempat lain. Sekarang ada orang lain yang mau tinggal bersama kami di sini, jadi kalian tidak usah datang kemari lagi."

6 Yukmo (Bahasa Balim) ialah wilayah tak bertuan yang sering menjadi medan perang antar konfederasi. 
Di Hepuba, para misionaris Katolik membangun sebuah sekolah katekis ${ }^{7}$ bagi anak-anak Assolokobal. Pada awalnya jumlah murid sangat sedikit, namun berkat perjuangan Guru Vincent Sukarno yang menetap di sana, pada 1966 sudah ada 29 murid. Para misionaris itu berpendapat bahwa Hepuba harus dilayani oleh seorang pastor yang tinggal secara menetap, karena di Sinata (Megapura), sebuah kampung yang berada di antara Kota Wamena dan Hepuba, telah ditempatkan 29 keluarga transmigran dari Jawa. Di antara mereka ada 10 orang guru, beberapa tukang kayu dan ahli membuat batu bata. Di sana mereka membangun juga sebuah sekolah dasar yang sekarang dikenal sebagai SD Negeri Megapura. ${ }^{8}$ Kehadiran para transmigran ini dipandang oleh para misionaris sebagai upaya menyebarkan agama Islam di Lembah Balim. Lieshout mengatakan bahwa proyek transmgrasi tersebut rupanya mempunyai tujuan tertentu, karena kebanyakan transmigran bukan berprofesi sebagai petani (Lieshout, 2009:223-224). Para transmigran tersebut sesungguhnya merupakan bagian dari gelombang kedatangan relawan Pelopor Pembangunan Irian Barat (PPIB) yang sudah dimulai sejak 1962 (Yamin, 2011). Kecurigaan terhadap pengiriman transmigran sebagai upaya Islamisasi mesti dipahami dalam konteks persaingan penyebaran agama yang lazim terjadi di antara agama-agama misioner tersebut. Tidak ada data yang mendukung atau pun menyangkal pandangan para misionaris tentang upaya penyebaran agama Islam ini. Namun kenyataannya, setelah kehadiran para transmigran tersebut, sejumlah anak di Megapura beralih masuk Islam. Anak-anak yang pertama kali masuk Islam antara lain: Musa Asso, Ibrahim Lani, Pawan Lokobal, Marjo Wetipo, Muhammad Asso, dan Warisno Lokobal. Hal itu terjadi sekitar tahun $1970 .{ }^{9}$

7 Sekolah katekis ialah sekolah yang mendidik pemuda-pemudi Gereja Katolik untuk menjadi pewarta Injil di kampung-kampung.

8 Menurut cerita Bapak Musa Asso, seorang tokoh muslim di Megapura, sekitar tahun 1966 itu datang sekitar 35 kepala keluarga transmigran asal Jawa Tengah. Mereka umumnya pasangan suami isteri tanpa anak.Di antara para transmigran itu hanya ada 3 orang anak yang masih kecil.Mereka tinggal di tiga barak panjang di Megapura.Barak tersebut kini menjadi SD Negeri Megapura.Para transmigran dari Jawa itu kemudian membangun rumahnya masing-masing di lokasi yang disediakan pemerintah, di antara Kali Posie dan Kali Etaget.

9 Ade Yamin (2011), menyebutkan bahwa generasi pertama orang Balim yang beralih memeluk Islam antara lain Musa Wuka, Sumarjo Wetipo, Idris Lokobal, Adam Wetipo, Okilik Lani, dan Said Lokobal.Peralihan orang Balim memeluk agama Islam juga terjadi di Kampung Welesi sebuah kampung yang berjarak sekitar $10 \mathrm{~km}$ di Barat Megapura, dan di Hitigima, sebuah kampung di Selatan Megapura. 
Sementara itu, di Hepuba misi Katolik memperoleh dukungan yang cukup baik dari para kepala suku. Para tetua adat di Hepuba menyediakan sebuah lokasi yang cukup luas untuk membangun kompleks Pos Misi Katolik. Pada 1966-1967 di tanah tersebut dibangun fasilitas pendidikan (SD), perumahan guru, dan pastoran. Seorang informan dengan sangat antusias menceritakan bahwa untuk membangun semua fasilitas tersebut masyarakat bergotong-royong memikul kayu dari hutan. Yang membuat mereka bersemangat ialah untuk mengerjakan semua itu pastor memberikan dan mengajari mereka menggunakan alat-alat kerja yang bagi mereka "baru", lebih kuat, dan lebih baik. Alat-alat baru itu dirasakan sangat mempermudah pekerjaan mereka, yakni kapak besi untuk menebang pohon, gergaji untuk memotong dan membelah kayu, parang untuk membabat semakbelukar, dan sekop untuk meratakan tanah. Alat-alat tersebut kemudian menjadi milik mereka yang ikut bekerja dan mereka gunakan untuk membuat kebun, pagar dan memperbaiki rumah mereka sendiri. Selain itu pastor juga menyediakan garam untuk memasak, tembakau dan korek api. Ketertarikan pada barang-barang baru yang mempermudah kehidupan, pengetahuan baru, serta pola hidup baru itu kemudian mendorong mereka untuk menjadi bagian dari komunitas baru tersebut. ${ }^{10}$

Perbedaan akses antara kelompok satu dengan kelompok lain terhadap berbagai hal baru kadang juga menimbulkan pergesekan antar kelompok. Lieshout (2009:224) menulis bahwa pada 1968 dan 1969 masyarakat dari Kampung Ilueagamo, daerah yang sekarang disebut sebagai Air Garam, ${ }^{11}$ wilayah isaeak Kuantapo (=Kuan-Wetapo), datang ke Hepuba, meminta agar pastor menempatkan seorang guru agama Katolik di wilayah mereka, padahal daerah mereka lebih dekat ke Hitigima. Bahkan jalan dari Air Garam ke Hepuba melewati wilayah orang Hitigima. Alasan utama mereka ialah, karena para misionaris CAMA mau memusnahkan adat mereka. ${ }^{12}$ Permintaan itu ditanggapi

${ }^{10}$ Bdk. Schwartz (1980) dan Strelan (1989) yang mengulas fenomena kultus kargo di Melanesia.Strelan (1989: 110) melihat kultus kargo sebagai"suatu refleksi religius atas jurang perbedaan budaya yang tajam antara peradaban Barat dan Melanesia.”.

11 Sebutan ini merujuk pada sebuah mata air asin yang ada di tempat itu, di kaki bukit, di ketinggian sekitar $1500 \mathrm{~m}$ di atas permukaan laut. Fenomena ini juga terdapat di daerah Kurulu (Lembah Balim bagian Utara.

12 Seorang guru agama Kingmi dari Kampung Air Garam mengatakan bahwa para pendeta tidak pernah membakar barang-barang adat.Masyarakat sendirilah yang sadar bahwa benda-benda adat itu (mugu, ap-warek, dan bareken) adalah berhala dan harus dibakar. Dengan kata lain, para pendeta bersifat persuasif menyadarkan umatnya, dan umat itu 
oleh Pastor Camps yang waktu itu melayani umat di Hepuba. Ia berunding dengan Pendeta B. Karcesky. Kesepakatan yang dicapai berbeda dengan harapan masyarakat setempat, yakni pihak CAMA yang justru menempatkan seorang guru di Ilueagama. Kepala suku Aikeak Asso, Sogokama, dan Ayekeak awalnya menolak kesepakatan tersebut, namun setelah kurun waktu cukup lama, akhirnya mereka menerima. Bahkan kepala suku besar Hitigima, Bapak Ukumhearik Asso, menurut Lieshout (2009:225) seumur hidupnya tidak pernah memilih dengan tegas antara CAMA dan Katolik. Ia mau bersahabat dengan para pendeta maupun pastor, namun tidak mengikat diri pada suatu pilihan tertentu. Walau demikian, konon Ukumhearik tidak pernah dibaptis, baik dalam Gereja Kingmi, Katolik atau Gereja mana pun. Ia menerima para pendeta dan pastor, tapi "tidak" secara resmi "menerima Injil" (Lieshout, 2009:225). Dengan kata lain, terjadi persaingan di antara para penyebar agama samawi itu untuk merebut simpati masyarakat.

Agama Kristen, baik Protestan maupun Katolik, yang datang bersama Pemerintah Belanda berusaha menanamkan pengaruhnya dan menarik orang Balim menjadi Kristen, sementara para pemeluk Islam yang datang seiring hadirnya Pemerintah Indonesia berusaha menarik perhatian masyarakat setempat untuk memeluk Islam. Ciri misioner ${ }^{13}$ yang melekat pada agama-agama samawi ini membuat para pemeluknya memandang kepercayaan tradisional Balim tidak memadai, kurang baik dibanding agama yang mereka peluk, dan harus ditinggalkan, diganti dengan cara hidup yang baru.

sendiri yang mengambil tindakan memusnahkan benda pusaka mereka. Namun informan lain menyangkal penjelasan seperti itu. Menurutnya, itu tidak benar.Tidak mungkin orang Balim membakar benda sakral mereka sendiri.' Kami takut.Orang tuatua dulu pasti juga takut nenek-moyang marah."'Menurutnya, para pendeta dan guru agama itu bukan melakukan persuasi dengan penjelasan yang lembut, melainkan menakut-nakuti masyarakat dengan kutukan dan ancaman. Kalau mereka masih menyimpan dan menyembah berhala, mereka akan masuk api neraka. Mereka terpaksa menyerahkan benda-benda adat itu untuk dibakar.

Menurut cerita para informan, pembakaran benda-benda adat juga dilakukan oleh tentara Indonesia.Mereka bukan hanya membakar benda-benda tersebut tapi sekaligus dengan honai-honai mereka.Hal terakhir ini biasanya dilakukan oleh aparat pemerintah sebagai hukuman terhadap kelompok-kelompok suku yang tidak mau berhenti berperang, atau melakukan perlawanan terhadap pemerintah.Pembakaran honai dan benda-benda adat di dalamnya, terutama terjadi saat "gejolak sosial" tahun 1977.

13 Tentang ciri misioner agama-agama samawi, lihat Lamb (1999), khususnya bagian Introduction. 


\section{Peralihan Agama, Penaklukan Budaya}

Kehadiran agama-agama samawi yang nota bene terbalut dalam sistem nilai lain (Eropa, Amerika, Flores, Arab, Jawa, dan sebagainya), di satu pihak memiliki andil besar terhadap terjadinya perubahan tata kehidupan masyarakat, khususnya dalam memperluas perspektif orang Balim tentang sesama manusia, namun di lain pihak luasnya perspektif relasi antarmanusia itu di sana-sini berperan besar dalam merelativir kuatnya pengaruh nilai-nilai adat terhadap cara berpikir dan bertingkah laku. Pengaruh paling besar tentunya dalam sistem kepercayaan. Dengan sedikit kekecualian di sana-sini, warna umum yang terwujud dalam relasi antar kedua sistem kepercayaan tersebut ialah dominasi ${ }^{14}$ agama samawi terhadap agama setempat.

Kehadiran para pendatang yang membawa sekian banyak hal baru, yang berbeda dari apa yang ada pada mereka, tampaknya memaksa mereka untuk tiba pada pemikiran (atau perasaan) bahwa apa yang ada pada mereka selama ini kurang baik, kurang sempurna dibandingkan apa yang dibawa oleh kaum pendatang (Schwartz, 1980). Pemikiran atau perasaan itulah yang rupanya mendorong sebagian penduduk asli untuk tunduk pada ajaran-ajaran agama baru dan mengapropriasi halhal baru yang hadir dalam kehidupannya. Misalnya, dalam pandangan agama asli, mugu, ap-warek, dan hareken, merupakan benda-benda yang dianggap sakral. ${ }^{15}$ Namun, bagi otoritas dogmatik agama-agama samawi benda-benda tersebut dipandang sebagai berhala. Melalui proses katekese/dakwah yang cukup lama, dan kadang juga dengan cara-cara yang tegas, larangan untuk berkiblat pada berbagai "berhala" itu relatif tidak mendapat perlawanan (lagi) dari umatnya. Kaum pendatang dan komunitas lokal itu kini menganut keyakinan yang relatif sama, sehingga komunitas lokal itu pada akhirnya menyetujui "penindasan" yang

${ }^{14}$ Dalam konteks ini, relevan kiranya memahami dominasi agama-agama samawi ini dalam kerangka pikir Bourdieu (1989) tentang kekuasaan simbolik.Menurutnya, kekuasaan simbolik mampu"membuat sesuatu hanya dengan kata-kata".Demikian pula Bourdeau (1977:1983-1997) tentang moda-moda dominasi yang terjadi dalam relasi antara manusia.

${ }^{15}$ Mugu ialah benda (bisa berupa tombak, panah, dan sebagainya) yang diambil dari "orang yang pertama dibunuh" dalam "perang pertama".Pembunuhan tersebut kemudian menjadi cikal-bakal terjadinya permusuhan turun-temurun antar konfederasi.Benda rampasan itu kemudian diresmikan sebagai benda sakral dan menjadi dasar didirikannya honai adat. Ap-warek ialah benda-benda yang diambil dari para musuh yang dibunuh dalam perang.Benda itu dapat berupa senjata (tombak, panah) perhiasan (hiasan kepala/kare-kare, manik-manik, dan sebagainya) atau pun bagian tubuhnya (rambut, jari, telinga). 
dilakukan para pemimpin dan guru-guru agama samawi tersebut. Secara sosio-religius, sebagian di antaranya menyerahkan diri untuk dibaptis, sebagian lagi masuk Islam, sebagian lagi tidak secara resmi menjadi Kristen atau Islam, namun menjadi bagian dari komunitas sosial agamaagama tersebut.

Walau demikian, dalam kehidupan sehari-hari menjadi jelas juga bahwa dengan menjadi Kristen atau Islam, tidak berarti bahwa mereka sepenuhnya meninggalkan keyakinan adat, yakni kepercayaan pada kekuatan alam dan peran para leluhur. Di sebuah kampung saya pernah menghadiri sebuah ritual penyembuhan. Walau secara formal mereka telah memeluk agama Katolik, namun dalam ritual tersebut mereka juga mohon penyembuhan kepada roh para leluhur dan mempersembahkan seekor anak babi. Dalam praktik keagamaan pun terjadi banyak saling penyesuaian (akulturasi) antara tradisi Balim dengan tradisi Katolik dan Protestan yang membawa serta kultur Eropa, antara tradisi Balim dengan tradisi Kingmi yang membawa kultur Amerika, atau pun antara tradisi Balim dengan tradisi Islam yang membawa kultur Arab-Jawa.

Kisah-kisah awal peralihan orang Balim menjadi Kristen atau Islam juga mengungkapkan bahwa peralihan-peralihan tersebut bukan pertama-tama (atau semata-mata) soal keimanan, melainkan (juga) realisasi taktik dan strategi komunitas lokal untuk membuka akses mereka terhadap tawaran-tawaran sosial, ekonomi, yang ada di depan mata. Kisah-kisah sejumlah orang tua di Assolokobal mengindikasikan bahwa peralihan menjadi Kristen digerakkan oleh kenyataan bahwa kehadiran kaum misionaris tersebut telah membawa suasana kehidupan yang berbeda. Orang Balim melihat sesuatu yang lebih, yang ada pada orang kulit putih dan tidak ada pada mereka. Orang-orang kulit putih itu memperkenalkan barang-barang yang secara kualitas lebih baik dari barang-barang lokal: misalnya, kapak besi dan parang yang lebih kuat dan tajam daripada kapak batu, sehingga orang dapat menebang pohon dan memotong kayu lebih cepat. Lebih dari itu, para misionaris tersebut kemudian juga membuka sekolah dan mengajarkan hal-hal (pengetahuan) baru, melayani mereka di bidang kesehatan dengan cara penyembuhan yang bagi mereka baru, dan mengajak serta mengajarkan mereka berdoa dan melakukan ibadah yang berbeda dari yang selama ini mereka lakukan. Kaum pendatang yang hadir dengan pakaian berbeda pun menjadi daya tarik tersendiri. Sebagian dari mereka kemudian juga mencoba mengenakan pakaian seperti para misionaris dan para guru. 
Hal semisal terjadi juga dalam relasi masyarakat lokal dengan para transmigran Jawa. Seorang tokoh muslim di Kampung Sinata (Megapura) menceritakan bahwa -ketika masih kanak-kanak- peralihan mereka menjadi muslim antara lain karena mereka tertarik dengan cara hidup kaum muslim dari Jawa yang waktu itu menjadi tetangga mereka. Bagi mereka yang pada waktu itu mengenakan holim dan sali/yokal, ${ }^{16}$ pakaian kaum pendatang itu sangat menarik, terlebih ketika mereka beribadah di mushola. Kaum laki-laki mengenakan peci dan berkain sarung, sementara kaum perempuannya memakai mukenah; pakaian yang dalam konteks masyarakat Balim tahun 1960-1970-an tentu sangat berbeda dengan yang mereka kenakan. Tokoh muslim tersebut juga menceritakan bahwa ia waktu kecil tertarik masuk Islam karena melihat "pak guru dan orang-orang Jawa" itu selalu sholat, dan sebelum sholat selalu didahului dengan berwudhu, sehingga wajah mereka selalu terlihat bersih. Menurutnya, yang menarik bagi mereka yang waktu itu masih kanak-kanak ialah kebersamaan di antara orang-orang Jawa pemeluk Islam tersebut. Di Bulan Ramadhan, orang-orang Jawa berkumpul di rumah-rumah secara bergiliran untuk berbuka puasa bersama dan sholat tarawih berjamaah. Saat Idhul Fitri suasana di rumah-rumah mereka ramai. Mereka berkumpul, beribadah bersama, dan makan bersama. Cara hidup itulah yang menurutnya menarik. Tokoh muslim tersebut juga menilai bahwa dengan kehadiran para transmigran tersebut orang Balim bisa melihat bagaimana orang mengolah tanah dengan cangkul, menanam padi dan sayuran. Melalui para transmigran, mereka juga belajar membuat batu bata dan memanfaatkan batang jagat (sejenis buluh) yang selama ini mereka gunakan untuk membuat batang anak panah, untuk dianyam menjadi dinding atau alas lantai rumah.

Hal yang secara bertahap sangat berperan penting mengubah kehidupan orang Balim di Assolokobal adalah pendidikan. Proses literasi tersebut bermula dengan didirikannya sekolah katekis di Hepuba pada sekitar tahun 1961, ${ }^{17}$ dan kemudian didirikan juga SD Negeri di Megapura pada 1966 oleh pemerintah Indonesia. Setahap demi setahap sekolahsekolah tersebut membuka wawasan anak-anak Assolokobal akan dunia pengetahuan. Dalam lingkup sekolah yang dikelola para misionaris Katolik, Lieshout (2009:224) mencatat bahwa jumlah murid pada SD

${ }^{16}$ Holim (Bahasa Mee: koteka) adalah pakaian laki-laki Balim, yang terbuat dari kulit buah labu yang dikeringkan. Sali adalah pakaian bagi para gadis, semacam rok yang terbuat dari anyaman kulit kayu.Adapun yokal adalah pakaian untuk kaum ibu (perempuan yang sudah menikah.

17 Sekarang sekolah tersebut dikenal sebagai SD YPPK St. Mikael Hepuba. YPPK: Yayasan Pendidikan dan Persekolahan Katolik. 
Hepuba pada 1967 ada 62 anak, di antaranya 12 anak perempuan. Jumlah ini bertambah terus. Pada akhir 1968 jumlah murid menjadi 80 orang, dan pada Juli 1969 sudah mencapai 113 anak. Namun Lieshout tidak menyebut berapa jumlah anak perempuan yang bersekolah pada Juli 1969 itu. Masuknya anak-anak perempuan ke sekolah, yang nantinya membuka pintu bagi mereka untuk terlibat dalam berbagai kegiatan di luar lingkungan rumah tangga (ranah publik) merupakan suatu perubahan yang sangat besar dalam budaya Balim, karena sebelumnya kehidupan kaum perempuan terbatas pada ranah domestik. Bersekolah bagi anak perempuan Balim pada masa itu adalah pengalaman yang sangat luar biasa, karena dengan demikian mereka bisa keluar dari lingkungan domestik dan masuk ke ranah publik, lepas dari asuhan dan lindungan orang tua, bergaul secara luas dengan anak-anak sebaya baik laki-laki maupun perempuan, dari bermacam klen lainnya,dan diperkenalkan juga dengan materi pendidikan yang berbeda, model pendidikan yang berbeda, dan sosok-sosok pendidik yang berbeda pula. Beberapa orang tua menceritakan bahwa guru mereka pada waktu itu antara lain pastor, dan seorang guru dari Paniai. Setelah itu ada menyusul seorang guru dari Jawa.

Tidak hanya dunia pengetahuan, pendidikan sekolah itu pada gilirannya juga mengantar anak-anak Balim di Assolokobal mengenal dunia luar. Mereka yang telah menyelesaikan jenjang pendidikannya di kampung, kemudian melanjutkan pendidikannya di Kota Wamena. Di antara anak-anak itu, setelah menyelesaikan SMP-nya di Wamena, sebagian melanjutkan pendidikan SMA atau SPG di Biak atau Jayapura. Mereka itulah yang antara lain sekarang menjadi guru di kampungnya dan menjadi pegawai di pemerintahan daerah.

Selain dunia pendidikan, kehadiran para penyebar agama itu juga mengenalkan mereka dengan varietas tanaman dan ternak baru. Seorang misionaris Katolik yang sering muncul dalam cerita orang Assolokobal ialah Pater Michael Angkur, asal Flores. Kehadirannya di Lembah Balim berawal pada Juni 1969. Dalam karyanya selama sekitar 8 tahun ia antara lain mendirikan sekolah dasar yang sekarang dikenal sebagai SD YPPK Santo Mikael Hepuba, dan mendidik masyarakat dalam bidang pertanian dengan memperkenalkan tanaman jagung, padi, dan kapas, serta beternak ikan. Lieshout (2009:225) menyebut bahwa pada 1970 Pater Michael bereksperimen dengan proyek percontohan, khususnya peternakan domba dan ikan, serta penanaman kapas dan kedelai.

Seorang bapak di Kampung Wiaima yang dulu juga bekerja pada kebun percontohan tersebut mengatakan bahwa Pater Michael pernah 
mengatakan kepadanya mengapa pater mengajak orang menanam tanaman tersebut. Berkait dengan jagung dan padi, menurutnya Pater mau memperkenalkan tanaman yang dimakan oleh kaum pendatang yang hadir di Balim, supaya kalau suatu ketika orang Balim suka makan jagung, orang tahu juga bagaimana menanamnya. Ketika orang Balim suka makan nasi, mereka juga tahu seperti apa itu tanaman padi, bagaimana menanamnya, bagaimana mengolahnya menjadi beras dan memasaknya menjadi nasi. Dengan menanam kapas, Pater mau menunjukkan kepada mereka tanaman yang dipintal menjadi benang dan menjadi bahan dasar kain dan dibuat menjadi pakaian. Namun, niat baik yang diwujudkan dalam proyek percontohan tersebut belum banyak berpengaruh pada dunia pertanian dan peternakan orang Assolokobal. Proyek tersebut berakhir seiring kepindahan Pater Michael. Tidak satu pun dari jenis tanaman tersebut yang masih menjadi bagian dari produk andalan orang Assolokobal. Kalau pun masih ada orang Assolokobal yang menanam jagung di kebunnya, jumlahnya sedikit saja, sekedar pelengkap di sela-sela kebun hipere (ubi jalar) atau di halaman rumah (sekitar silimo). Keengganan mereka untuk mengembangkan komoditas yang berbeda itu antara lain karena kebutuhan akan komoditas tradisional tersebut masih cukup tinggi.

Aneka perubahan yang terjadi sebagai dampak interaksi orang Balim dengan kaum pendatang dari agama yang berbeda itu berpengaruh pula pada cara pandang mereka terhadap alam, sesama dan Yang Ilahi. Pemaknaan terhadap simbol-simbol, ritual, relasi sosial, dan tata kehidupan dalam berbagai aspeknya pun berubah. Sebagai contoh, kekhasan budaya yang paling kasat mata bila kita masuk ke kampung-kampung di Lembah Baliem ialah perkampungan (silimo) dengan honai, ebeai, lesai (lesse), dan wam-aila-nya. Secara keseluruhan tata perumahan itu memuat kosmologi dan tata sosial orang Balim, dan menjadi ruang paling akrab dalam membangun relasi antar pribadi maupun antar kelompok. ${ }^{18} \mathrm{Akibat}$ perubahan zaman dan peralihan keyakinan agama, sebagian bangunan tradisional itu telah berganti (atau berdiri berdampingan) dengan rumah papan, rumah semi permanen, hingga gedung berdinding tembok beratap seng, dengan bentuk eksterior dan tata ruang yang berbeda dari alam pikiran warisan leluhurnya. Ruang sakral yang sebelumnya ada dalam honai, kini berpindah ke masjid atau

18 Silimo ialah satu kesatuan hidup bersama(=uma). Sili, merujuk pada halaman tentang yang dikelilingi honai, ebe-ai, les-ai, dan wam-ai. Honai: rumah laki-laki, ebe-ai: rumah keluarga, les-ai (lese): dapur, dan wam-ai: kandang babi. 
gedung gereja. Relasi-relasi dalam hidup bersama pun mengalami perubahan. Tata hidup bersama yang sebelumnya berfondasi pada paham keluarga luas, sedikit demi sedikit mulai bergeser ke keluarga batih. Dalam masyarakat Balim yang menganut Kristen, tata hidup berumah tangga yang sebelumnya memandang poligami sebagai hal yang wajar, sedikit demi sedikit mulai tergerus oleh pandangan yang mengunggulkan nilai monogami. ${ }^{19}$ Sementara di kalangan masyarakat muslim, perubahan dalam hal tersebut tidak terjadi.

Sikap agama-agama samawi terhadap budaya Balim cukup berbeda antara satu dengan yang lain. Di wilayah-wilayah pelayanan Gereja Kingmi dan Pentekosta, benda-benda adat seperti mugu, dan hareken (kaneke) sudah dibakar pada masa awal kedatangan para misionaris.Namun, mengenai siapa yang membakar hareken tersebut, pendapat antar informan bisa berbeda-beda. Ada yang mengatakan bahwa para misionarislah yang membakarnya.Tapi, ada juga yang mengatakan bahwa para tetua adat sendirilah yang membakarnya, setelah "sadar" bahwa benda-benda tersebut adalah berhala. Namun, seorang informan lain mengatakan bahwa kedua caraitu (paksaan dan persuasif) memang terjadi. Lepas dari siapa pelaku yang de facto membakar benda-benda adat tersebut, jelaslah bahwa dalam proses tersebut telah terjadi praktik penguasaan ide, praktik monopoli kebenaran, dan apa yang dianggap tidak benar harus dimunahkan. Kebenaran suatu nilai berkait erat dengan kekuasaan. ${ }^{20}$ Dengan pembakaran benda-benda adat tersebut masyarakat adat "disadarkan" (lebih tepat, "dipaksa/diarahkan untuk menganggap") bahwa benda sakral mereka adalah berhala, berhala itu buruk, dan karena itu harus dimusnahkan.

19 Poligami seringkali menjadi penghalang untuk secara resmi menjadi Kristen. Di kampung-kampung yang mayoritas menganut agama Katolik, banyak di antara mereka yang memiliki lebih dari satu isteri memilih untuk tidak dibaptis demi mempertahankan cara hidup berkeluarga yang mereka yakini baik dan tak ingin mereka tinggalkan. Apalagi, Gereja tidak melarang mereka untuk bergabung dalam ibadat bersama dan terlibat dalam dinamika sosial Gereja, walau tidak mengizinkan mereka untuk mengambil bagian dalam hidup sakramental Gereja. Halangan ini tidak mereka alami bila mereka beralih menjadi muslim.

${ }^{20}$ Bandingkan pandangan Foucault (dalam Gordon, 1977:133): “Truth' is to be understood as a system of ordered procedures for the production, regulation, distribution, circulation and operation of statements. 'Truth' is linked in a circular relation with systems of power which produce and sustain it, and to effects of power which it induces and which extend it. A 'regime' of truth." 
Dalam perkembangannya, ritual agama samawi pun secara perlahan namun pasti mulai menggusur ritual-ritual adat. Pesta dan upacara adat seperti ap-waya (inisiasi anak laki-laki), he yokal (inisiasi anak perempuan), pawi (pertobatan/pemulihan relasi yang terganggu akibat inses) semakin jarang dilakukan. Kalau pun masih diselenggarakan, sudah terjadi banyak penyesuaian dengan ajaran agama baru yang dianut dan kondisi masa kini. Bagi orang-orang tua kesan kekhusukan dan tafsir nilai pada setiap detil ritusnya pun sudah berbeda. Di Assolokobal, pesta raya babi (wam mawe) yang merupakan pesta adat sentral dalam budaya Balim terakhir dilaksanakan pada awal 90-an. Itu berarti sudah sekitar 20 tahun yang lalu. Padahal dalam pesta tersebut dilaksanakan berbagai upacara yang sangat penting bagi masyarakat Balim, seperti menghormati arwah leluhur dengan membersihkan batu sakral dan mempersembahkan babi (wam-kaneke), inisiasi,dan perkawinan. Dalam pesta akbar tersebut terjadi pembaruan relasi antar kerabat, melalui pertukaran babi (wam) dan su (noken). Yang tidak kalah penting ialah pemberian penghargaan atas anggota konfederasi atau pun aliansi yang gugur dalam perang, sekaligus mengakhiri masa duka atas kematiannya. Sebagai penghargaan dan pengikat relasi antar-isaeak, mereka membuat hareken baru bagi para pahlawan tersebut.

Pasca kehadiran agama-agama samawi, ritual-ritual adat itu pun sedikit demi sedikit ditinggalkan. Seorang pendeta Gereja Pentekosta menjelaskan pandangan Gereja Pentekosta terhadap adat setempat. Menurutnya, Gereja Pentekosta tetap menghargai adat setempat, tapi menolak untuk menjadikannya bagian dari tata hidup Gereja. Gereja tidak bisa melarang adat tumbuh dan berkembang dalam masyarakat, tapi Gereja tidak mungkin menyesuaikan diri dengan adat. Segala yang berkait dengan kepercayaan kepada leluhur, dan praktek-praktek yang berkait dengan itu harus ditinggalkan. Ia memberi contoh, "bunuh babi", yakni proses memanah dan menyembelih babi dalam suatu pesta Natal tetap boleh, tapi tidak boleh dilakukan dalam tata cara adat Balim. Penyiapan daging babi sebagai sajian dalam acara Gerejani atau acara lain oleh orang yang sudah memeluk Pentekosta, harus diawali dengan doa secara kristiani, entah oleh pendeta, atau majelis, atau salah seorang di antara yang hadir. Pendeta tersebut juga mengatakan, tetua adat yang masih menyimpan bareken dalam honainya, tidak boleh dibaptis. Mereka boleh ikut dalam kegiatan umat sebagai simpatisan, tapi tidak bisa dibaptis atau diterima secara resmi sebagai anggota Gereja. Dalam sebuah percakapan saya dengan dua anak muda dari sebuah Gereja pertobatan, mereka secara spontan menyebut benda adat mereka sendiri 
(hareken, apwarek, mugu, dan sebagainya) sebagai "berhala". Bagi mereka pilihannya jelas dan tegas, yaitu dibaptis berarti meninggalkan kepercayaan adat. Karena itu benda-benda adat warisan leluhur itu harus dimusnahkan. Orang yang masih mempertahankan barang-barang adat, tidak bisa dibaptis.

Tergusurnya tradisi setempat juga tampak dalam upacara pembakaran jenazah. Gereja-gereja pertobatan umumnya berpandangan bahwa orang yang sudah dibaptis, saat meninggal harus dikubur. Demikian pula pandangan umat Islam.Masalah pernah muncul di sebuah kampung yang menjadi wilayah Gereja Kingmi (GKII), karena status keagamaan almarhum tidak jelas, apakah sudah resmi menganut Kristen atau belum, sementara kaum kerabatnya sebagian sudah dibaptis dan yang lain belum. Dalam situasi tersebut muncul perdebatan antarkedua kubu.Mereka yang sudah dibaptis dalam Gereja Kingmi mengatakan bahwa jenazah harus dikubur, sementara mereka yang belum dibaptis menuntut agar jenazah itu dikremasi sesuai aturan adat. Jalan damai yang kemudian diambil ialah menyerahkannya pada kesepakatan keluarga almarhum yang paling dekat, yakni kakak, adik dan orangtuanya yang nota bene penganut Kingmi. Akhirnya, jenazah pun dikuburkan.

Seorang pendeta Gereja Pentekosta di Megapura menjelaskan pada saya peraturan yang berlaku di Gerejanya, bahwa bila seseorang adalah simpatisan Gereja Pentekosta tapi belum resmi dibaptis, seluruh proses perlakuan terhadap jenazah diserahkan pada sanak keluarganya. Apakah jenazahnya hendak diperabukan secara adat ataukah akan didoakan secara kristiani, keputusan diserahkan pada pihak keluarga. Menurutnya, "Gereja tidak bisa menolak atau memaksakan satu cara". Tapi, apabila almarhum sudah resmi dibaptis secara Pentekosta, maka Gereja wajib melayaninya menurut tatacara kristiani. Selanjutnya, apakah jenazahnya akan diperabukan atau dikubur, silakan keluarga memutuskan, asalkan segala upacara yang berkait dengan kepercayaan adat tidak lagi dilakukan.

Sikap Gereja Katolik terhadap adat Balim tampaknya lebih akomodatif. Di kalangan Gereja Katolik keharusan untuk dikubur atau diperabukan tidak dipermasalahkan. Keduanya diakui dan dianggap baik, dan orang Balim Katolik umumnya memilih untuk memperabukan orang yang meninggal. Upacara perabuan itu pun dilayani menurut tata cara Katolik sebagaimana halnya upacara penguburan. Setelah jenazah diperabukan dan upacara Gerejani selesai, sejumlah ritual yang berkait dengan kepercayaan adat pun kadang masih dilakukan. Menurut 
pemimpin Gereja setempat, yang penting umat melakukannya sekedar sebagai tradisi untuk menghormati arwah orang yang meninggal dan menghormati para leluhur, serta tidak mengganggu iman kristiani mereka. Sikap agama Islam tampaknya lebih ketat dan tegas, sehingga tidak tampak adanya penyesuaian dalam tatacara ritual kematian. Semua umat muslim yang meninggal harus dikuburkan menurut tata cara Islami, dan segala bentuk ritual adat tidak boleh dilakukan.

Dalam fenomena perubahan hidup beragama tersebut jelas terlihat bahwa orang Balim dengan kepercayaan dan budayanya seringkali berada dalam posisi terdominasi, dan menjadi objek pemurnian atau pemberadaban. Gereja-gereja yang bekerja di Lembah Balim, memiliki karakter yang berbeda satu sama lain, namun sampai kini pun jelas terlihat karakter khas para misionaris bahwa mereka datang untuk "menunjukkan jalan terang" pada kaum yang dianggap masih "berjalan dalam kegelapan"(Hayward, 1980). Orang-orang yang masih hidup dalam lingkup kepercayaan adat dipandang sebagai penyembah berhala, yang perlu dibantu supaya menjadi lebih layak di hadapan Allah, bersama dengan manusia lain dalam budaya kristiani. Dengan kosa kata yang berbeda,praktik yang kurang lebih sama pun terjadi di kalangan Islam,antara lain dengan adanya pembedaan yang cukup tegas antara "kaum beriman" dan "kafir" (infidel, heathen) (Lamb, 1999:10).

Dalam praktik penyebaran agama, tampak bahwa hanya sebagian penyebar agama yang betul-betul peduli pada manusia dan budaya Balim sebagaimana adanya, sementara sebagian lainnya bersikap sebagai "agen pembaruan", tanpa menyadari bahwa sikap tersebut menghadirkan pola relasi yang mengaburkan kesetaraan antar budaya. Mereka seolah abai, apakah sedang berdialog dengan sesama manusia ataukah sedang menjadikan sesamanya sebagai objek pemanusiaan. Peristiwa yang dari sudut pandang agama samawi dilihat sebagai peristiwa pertobatan dan langkah untuk meraih keselamatan, dari sudut pandang perubahan sosial budaya dapat dikatakan sebagai suatu proses penaklukan (Buckser, 2003:63). Budaya dan kepercayaan lokal yang telah berperan menata kehidupan bersama suatu komunitas dalam rentang perjalanan sejarah yang demikian panjang, dipersuasi/dipaksa tunduk pada budaya dan sistem kepercayaan lain. Tidak mengherankan bahwa peristiwa penaklukan budaya semacam itu kemudian memunculkan fenomena budaya yang dari sudut pandang fanatisme agama samawi, terlihat sebagai hal yang aneh dan sulit diterima. Misalnya, saya pernah menghadiri sebuah ritual penyembuhan adat di sebuah kampung. Walau mereka sudah menganut agama Katolik, namun ketika sakit -selain ke 
rumah sakit- mereka juga masih mengupayakan penyembuhan melalui para dukun (Balim: wesagun). Di kampung yang mayoritas muslim, saya juga menemukan sejumlah orang yang memelihara babi, hewan yang sangat penting dalam adat balim namun dipandang haram dalam ajaran Islam. Dalam percakapan santai, diceritakan juga bahwa anakanak muda Balim, walau sudah menganut Islam, kadang secara diamdiam juga ikut menyantap daging babi.

Sebagaimana perubahan sosial-budaya pada berbagai suku, perubahan yang terjadi di Lembah Balim telah mengantar banyak orang Balim ke dalam pergumulan antara keinginan mempertahankan budaya warisan leluhur dan menerima pengaruh budaya lain yang tak jarang 'menuntut' mereka meninggalkan tradisi nenek-moyangnya. Sebagai sukubangsa yang relatif belum lama mengalami interaksi yang intensif dengan budaya lain, ${ }^{21}$ di satu pihak, generasi yang hidup dalam naungan adat para leluhur masih hidup dan cukup berpengaruh. Di lain pihak, generasi yang lebih muda umumnya dibesarkan dalam pengaruh tradisi Kristen atau Islam, mengenyam pendidikan modern, dan menjalani hidup dalam pengaruh dinamika masyarakat perkotaan yang heterogen. Generasi muda ini sedikit demi sedikit mulai meninggalkan simbolsimbol budaya leluhurnya dan menjalani hidup dalam interaksi yang semakin intensif dengan dinamika zaman yang dalam banyak hal jauh dari cara pandang para orang tua dan leluhur mereka.

\section{Catatan Reflektif}

Interkoneksi global yang terjadi di Lembah Balim telah mengubah bentang alam, komposisi kesukubangsaan, pola kehidupan masyarakat, dan banyak hal lainnya.Proses tumbuh kembang budaya baru, cara hidup baru, pola berpikir baru dalam penghayatan nilai yang berbeda, terus berlangsung. Dalam proses perubahan itu ajaran agama-agama samawi menjadi salah satu faktor yang cukup berpengaruh, di antara sekian

${ }^{21}$ Bila melihat persamaan benda khas adat, seperti kapak batu, manik-manik, bentuk mata anak panah, boleh jadi mereka sudah sejak lama berelasi dengan sesama orang Papua. Menurut laporan Veldkamp (Schoorl, 2001:61), interaksi intensif antara orang Dani dengan pendatang dari luar Papua terjadi pada pertengahan abad ini, karena “... Meskipun sudah ditemukan dari udara pada 1938, sampai jauh ke tahun 1950-an lembah tersebut tetap tanpa pemerintahan (Belanda). Pembangunan pos di daerah itu akan menuntut sumber daya besar, terutama karena kesulitan pembekalan yang hanya dapat dikerjakan melalui udara. Hingga akhir 1956 baru ada satu pos pemerintah di pegunungan tengah, yaitu Enarotali di tepi Wisselmeren, 300 kilometer lebih ke arah barat." 
banyak hal lain seperti uang, barang, pendidikan, politik pemerintahan, dan sebagainya.

Masuknya agama sebagai bagian dari arus besar budaya, langsung menusuk ke jantung kehidupan orang Balim dan secara fundamental mempengaruhi kehidupan mereka. Terbentuknya komunitas-komunitas baru atas dasar agama yang dipeluknya, pada gilirannya juga mempengaruhi cara mereka berpikir, bertindak, dan berelasi dengan alam, sesama dan Yang Ilahi. Di satu pihak, sejarah membuktikan bahwa kehadiran agama samawi di Lembah Balim telah membawa banyak pengaruh baik, antara lain karena meluaskan paham tentang sesama yang lintas sukubangsa. Perubahan sosial dan peralihan agama tersebut menggambarkan keterbukaan orang Balim untuk berelasi lintas budaya, dan menunjukkan kelenturan mereka untuk menerima nilai-nilai baru ke dalam budayanya. Di lain pihak, perubahan sosial dan peralihan agama tersebut (betapapun halus caranya) menggambarkan ketidakseimbangan relasi antar budaya, sekaligus menyajikan kisah penaklukan "komunitas lama" oleh para aktor baru yang datang dengan membawa simbol-simbol kuasa modernitas (teknologi, barang-barang baru, kemudahan hidup, pengetahuan, uang). Hegemoni para aktor baru itu memaksa masyarakat lokal mengubah identitasnya menjadi "komunitas baru", menjadi orang Balim Kristen, orang Balim Katolik, orang Balim Islam, dan sebagainya.

Peristiwa semisal -yang terjadi di berbagai belahan duniamenyiratkan, betapa komunitas lokal dengan kesederhanaannya begitu rentan terhadap pengaruh nilai-nilai baru yang dibawa oleh kaum pendatang. Agama-agama samawi -yang tumbuh dan berkembang dalam dinamika teknologi transportasi dan komunikasi yang canggih- tampak begitu "mudah" memenangkan pertarungan wacana etis tentang "hidup baik", "hidup bahagia", dan semacamnya. Lebih dari itu, agama-agama samawi yang datang dengan etosnya sebagai agama misioner, berhasil pula memenangkan wacana eskatologis tentang "jalan keselamatan" dan "kebahagiaan abadi", yang dianggap lebih "afdol" dibandingkan jalan keselamatan yang sudah dijalani oleh masyarakat lokal itu selama sekian generasi.

Pemelukan agama baru, entah Kristen atau pun Islam, bukanlah semata-mata peristiwa peralihan subjek kepercayaan. Daya tarik suatu komunitas religius bukan saja karena ajarannya tapi juga bagaimana cara hidup pribadi-pribadi anggotanya dan kehidupan bersama komunitas tersebut. Ketertarikan untuk menjadi bagian dari suatu komunitas agama, seringkali terjadi karena relasi kemanusiaan yang 
sederhana namun mempengaruhi kehidupan bathin manusia secara mendalam, baik dengan mengalami hidup bersama sehari-hari, maupun melalui pelayanan pendidikan dan kesehatan. Peralihan agama dan proses pembentukan komunitas dalam satu agama bukan semata-mata suatu "peristiwa iman", melainkan juga bagian dari "proses berkebudayaan", bagian dari strategi untuk membuka akses pada kehidupan yang dianggap lebih baik, entah secara ekonomi, sosialpolitik, atau pun spiritual.

Dalam realitas semacam itu agama-agama samawi-sebagai pihak yang seringkali berada pada posisi dominan- kiranya ditantang untuk menghadirkan wajahnya sebagai "jalan keselamatan” yang sungguh manusiawi dan berbudaya, bukan sekedar sebagai subjek-subjek yang sok kuasa, sok benar, sok tahu, dan sebagainya. "Kemuliaan kebenaran" yang dihadirkan para penganut agama samawi kiranya justru akan semakin tampak dalam "kemuliaan hidup manusia" yang dihadirinya.

\section{Daftar Pustaka}

Bourdieu, Pierre. 1977. Outline of a Theory of Practice. Terjemahan R. Nice dari teks asli tahun 1972, Volume 16. Cambridge: Cambridge University Press.

—. 1989."'Social Space and Symbolic Power", dalamSociological Theory, Vol. 7, No. 1 (Spring, 1989), pp. 14-25 Published by: American Sociological Association Stable URL: http://www.jstor.org/ stable/202060 Accessed: 17/02/2009 23:12

Buckser, Andrew dan Stephen D. Glazier. 2003. The Anthropology of Religious Conversion. Lanham: Rowman \& Littlefield Publishers, Inc.

Cookson Michael. 2000."The Archbold Expeditions to New Guinea: A Preliminary Survey of Archival Materials Held at the American Museum of Natural History, New York City," dalam The Journal of Pacific History, Vol. 35, No. 3 (Dec., 2000), pp. 313318. Published by: Taylor \& Francis, Ltd. Stable URL: http:// www.jstor.org/stable/25169504 Accessed: 12/08/2010.

Gordon, Colin (Ed.). 1977. Power/Knowlwdge. Selected Interviews and Other Writings 1972-1977 Michael Foucault. New York: Pantheon Book.

Hayward, Douglas. 1980. The Dani of Irian Jaya Before and After Conversion. Sentani, Irian Jaya: Regions Press. 
Lamb, Christopher, dan Bryant, M. Darrol (Ed.). 1999. Religious Conversion: Contemporary Practices and Controversies. London dan New York: Cassell.

Lieshout, Frans. 2009. Gereja Katolik di Lembah Balim - Papua. Kebudayaan Balim Tanah Subur bagi Benih Injil. Jayapura: Sekretariat Keuskupan Jayapura.

Schoorl, Vim (Penyunting). 2001. Belanda di Irian Jaya. Amtenar di Masa Penub Gejolak. 1945-1962. Kata Pengantar George J. Aditjondro. Jakarta: Perwakilan KITLV dan Penerbit Garba Budaya.

Schwarz, Brian. 1980. "Seeking to Understand Cargo as a Simbol", dalam Catalyst volume 10, no. 1. Goroka, PNG.

Strelan, Dr. John G. dan Drs. Jan A. Godschalk. 1989. Kargoisme di Melanesia - Suatu Studi tentang Sejarah dan Teologi Kultus Kargo. Jayapura: Pusat Studi Irian Jaya.

Yamin, Ade. 2011. "Sejarah Masuknya Islam ke Wamena-Papua (2)," dalam Etnohistori.org, 11 Mei 2011. . 2011. "Generasi Pertama orang Dani Pemeluk Islam (3)", dalam Etnohistori.org. 